\title{
Riding the storm out: select demographics of a breeding population of Cooper's hawks (Accipiter cooperii) following a severe spring snowstorm
}

\author{
Prežit' búrku: vybrané charakteristiky hniezdnej populácie jastraba čiapočkatého \\ (Accipiter cooperii) po silnej jarnej snehovej búrke
}

\author{
Robert N. ROSENFIELD
}

\begin{abstract}
The demographic responses to severe weather by top-level predators, including birds of prey, are underreported and/or unknown. Severe storms are predicted by climate change models to increase globally and in frequency into the $22^{\text {nd }}$ century. In April 2018, a population of breeding Cooper's hawks (Accipiter cooperii) in central Wisconsin, USA, experienced three days of heavy snowfall in the most severe storm, in pre-incubation-stage, for 39 years (1980-2018). Here I report select demographic outcomes of this nesting population following this intense weather. The median hatching date of 10 June in 2018 was the sixth latest such metric in those 39 years (and the latest in 22 years since 1996) for this population, which has advanced its breeding schedule about 1.3 days/decade due to climate change or warming. Survival of a total of 16 color-marked breeding adults, 15 males and 1 female, observed pre-storm in the nesting areas, was $100 \%$ up through the late nestling stage in the same nesting areas where these birds were initially detected in 2018. Average clutch size (4.4 eggs/nest) and average brood size (4.0 young/ nest) were similar to the overall average annual metrics of these demographics for this population in the earlier 38 study years. Nest success, whereby $95 \%$ of 21 nests with eggs produced advanced-aged young, was higher in 2018 than the overall average of $77 \%$ nest success rate during the earlier years. The later timing of hatching in 2018 , likely due to the severe spring snowstorm, appeared to have no deleterious effects either on survival of the breeding adults or on the reproductive output of this healthy study population. Tree-canopy prey may have served as important alternative food for this typically ground-foraging raptor in 2018 .
\end{abstract}

\begin{abstract}
Abstrakt: Demografické reakcie na nepriaznivé počasie vrcholovými predátormi, dravce nevynímajúc, sú nepublikované a/alebo neznáme. Klimatické modely predpovedajú celkový nárast výskytu búrok aj ich frekvencie do 22 . storočia. V apríli 2018 zažila hniezdna populácia jastraba čiapočkatého (Accipiter cooperii) v centrálnom Wisconsine, USA, tri dni silného sneženia v najsilnejšej búrke v predinkubačnom období za posledných 39 rokov $(1980$ - 2018). V tomto príspevku uvádzam vybrané demografické charakteristiky tejto hniezdnej populácie po tomto silne nepriaznivom počasí. Stredný dátum liahnutia - 10. júna v roku 2018 bol šiestym najneskorším počas posledných 39 rokov (a najneskorší počas 22 rokov od roku 1996) pre túto populáciu, ktorá v dôsledku klimatických zmien alebo otepl'ovania urýchlila termín hniezdenia o 1,3 dňa/desat'ročie. Prežitie celkovo 16 farebne označených hniezdiacich dospelých jedincov, 15 samcov a 1 samice, pozorovaných pred búrkou v hniezdiskách bolo $100 \%$ do posledných fáz hniezdenia v rovnakých hniezdiskách, kde boli tieto vtáky prvykrát zistené v roku 2018. Priemerná vel'kost' znášky (4,4 vajec/hniezdo) a priemerný počet mlád’at (4,0 mladé/hniezdo) boli podobné celkovým priemerným ročným hodnotám charakteristík tejto populácie v predchádzajúcich 38 študovaných rokoch. Hniezda úspešnost', ked' v 95 \% z 21 hniezd so znáškou boli odrastené mlád’atá, bola v roku 2018 vyššia než 77 \% celková priemerná hniezda úspešnost' v predchádzajúcich rokoch. Neskoršie načasovanie liahnutia v roku 2018, pravdepodobne v dôsledku silnej jarnej snehovej búrky, nemalo žiaden škodlivý účinok ani na prežitie hniezdiacich dospelých jedincov, ani na reprodukciu tejto životaschopnej populácie. Korist' viazaná na koruny stromov mohla slúžit’ ako dôležitá alternatívna potrava pre tohto na zemi loviaceho dravca v roku 2018.
\end{abstract}

Key words: demographic response, severe weather, hatching date, survival, climate change, Wisconsin, USA

Robert N. Rosenfield, Department of Biology, University of Wisconsin at Stevens Point, Stevens Point, Wisconsin, USA 54481. E-mail: rrosenfi@uwsp.edu.

Acknowledgments: I thank all the private landowners who permitted me access to Cooper's hawk nests on their property. The Biology Department, Personnel Development Committee, and the Letters and Science Foundation at the University of Wisconsin at Stevens Point provided funding. I extend special gratitude to Larry E. Sobolik and Madeline G. Hardin for their varied support of this long-term research. I also thank John A. Roth for the photo of the April 2018 snowstorm from my Wisconsin study area. The remarks of Artur Golawski and an anonymous referee greatly improved this paper. 
Rosenfield RN: Riding the storm out: select demographics of a breeding population of Cooper's hawks (Accipiter cooperii) following a severe spring snowstorm

\section{Introduction}

Future climate-change scenarios predict that storm events, including low temperatures, tornados, hail, and high amounts of precipitation will increase in severity and globally in many areas, including the western Great Lakes region of North America (Serbin \& Kucharik 2009, Wellicome et al. 2014, USGCRP 2017). Our knowledge of the consequences of recent climate change including adverse weather on wildlife are limited (Hunter et al. 2010, Franke et al. 2013, Anctil et al. 2014), although some information is available for some well-studied Arctic species (e.g., geese [Dickey et al. 2008], seabirds [Gaston et al. 2005], and polar bears [Ursus maritumus; Stirling \& Derocher 2012]). Moreover, some bird groups such as raptors have received much less attention than others regarding their response to adverse weather (Møller et al. 2010). Similarly, discussions of conservation of raptor species in two recent review papers (Newton et al. 2016, McClure et al. 2018) did not address the threat of climate change and/or adverse weather to raptor populations.

Precipitation, usually in the form of rain, is an important, if not primary component of severe weather which often adversely influences breeding success of avian species (Lõhmus 2003). Periods of intense and/or prolonged rain or snow, especially early in the breeding season, increase the risk of egg loss and hypothermia for the young, and degrade hunting conditions for adults in part by reducing food availability (e.g, prey species are often inactive during stormy weather and thus difficult to detect; Krüger 2004, Whelan et al. 2017). Intense poor weather also increases the risk of predation and starvation for stressed adults (Rodriguez \& Bustamante 2003, Krüger 2004, Franke et al. 2013, Whelan et al. 2017). Poor spring weather can cause nest abandonment and reduce overall reproductive success of birds, including birds of prey (Whelan et al. 2017).

In response to recent and rapid climate change, especially warming spring temperatures, Wisconsin Cooper's hawks in the Great Lakes region have advanced their egg-laying on average by about 4-5 days during 1980-2015, concordant with advanced spring phenologies of 55 Wisconsin species of plants and migratory songbirds (Rosenfield et al 2016). Notably, some of these birds, including particularly the groundforaging American robin (Turdus migratorius), are primary prey of this raptor especially during the pre-incubation period (Bradley et al. 1999, Rosenfield et al. 2016). It is conceivable that some of these phenological advancements may create a mismatch between the tim- ing of (reduced) availability of prey and optimal broodrearing time for Cooper's hawks with consequential deleterious effects on their production and other demographics (Wellicome et al. 2014, Whelan et al. 2017). However, there have been no adverse effects on the average, relatively high and stable reproductive indices of this population of Cooper's hawks during the 36-year period (Rosenfield et al. 2016).

That said, the study area experienced a severe spring storm during 14-16 April 2018 (defined as $\geq 3$ days of consecutive heavy precipitation [sensu Anctil et al. 2014]), which included $508 \mathrm{~mm}$ of snowfall (including $76 \mathrm{~mm}$ of rain), with about $381 \mathrm{~mm}$ of snow on the ground for four days during 15-18 April (National Climatic Data Center website; see Fig. 1). Cooper's hawks are a partially migratory species in Wisconsin (i.e. some birds are present year-round, even at nesting sites), and most breeding birds are at their nesting sites for about $1-$ 3 weeks prior to mid-April. Earliest nesting pairs in many years will begin laying eggs around 20 April (Rosenfield 2018). Combined snow and rainfall during 14-16 April 2018 averaged about $10 \times$ higher (range $=3-$ $62 \times$ ) than any other 3-day maximum amount of combined snow and rainfall in April during the preceding 38 study years. The average number of days with ground snow cover in April during 1980-2017 was 1.2 days (there were 20 days of snow cover in April 2018); and the average amount of daily snow depth on the ground in April during 1980-2017 was $\leq 25 \mathrm{~mm}$ (National Climatic Data Center website).

Wisconsin Cooper's hawks are principally groundforaging predators, and snow cover may limit access to ground-dwelling prey, which includes songbirds, the mourning dove (Zenaida macroura), and small mammals (especially eastern chipmunks, Tamias striatus). Availability of such prey may trigger egg-laying in Wisconsin Cooper's hawks (Rosenfield et al. 2016). The intense spring storm in 2018 precluded for the first time in 39 years my travel to my Cooper's hawk study nests because virtually all roads (and landscapes) became impassable with deep, wet snow for four days following the storm in and around Stevens Point, Wisconsin (Fig. 1). This city is my residence and the geographic center of my mid-Wisconsin study area. Notably, during about two weeks following this storm, unsolicited communication with the general public about their detections of 'high numbers' of dead birds in my study area demonstrated local concern about the possible population effects of this 'historic' storm. 


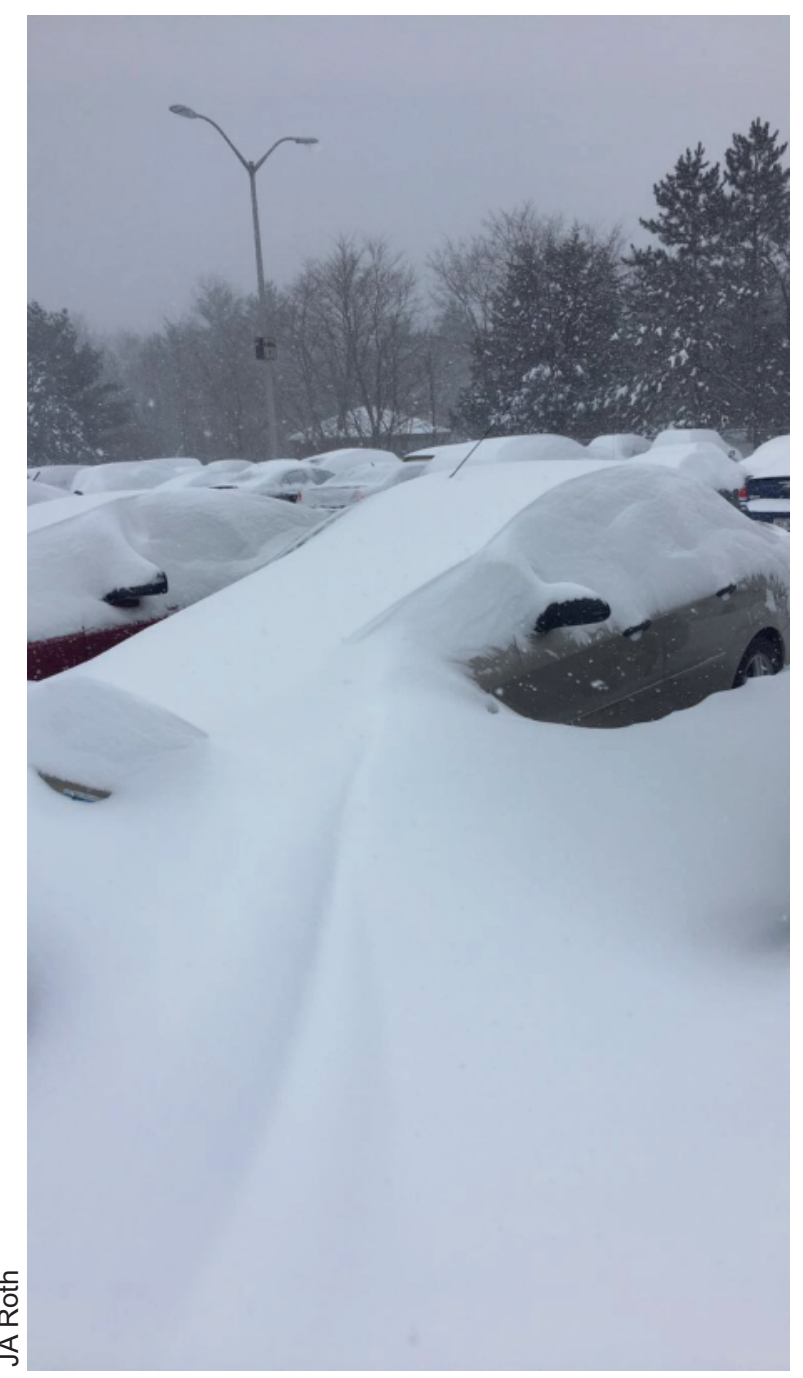

Fig. 1. Heavy snowfall during a severe, mid-April 2018 storm in Stevens Point, Wisconsin, near the center of our Cooper's Hawk study area.

Obr. 1. Silné sneženie počas prudkej búrky $v$ polovici apríla 2018 v Stevens Point, Wisconsin, blízko stredu študijnej plochy jastraba čiapočkatého.

My objective was to document the breeding phenology and reproductive success of the study population in the storm's aftermath, in addition to the nesting season survival of marked adults observed at their breeding sites 5-15 days prior to this severe April weather. Although I place some of my results in the ecological context based on analyses of similar, long-term demographics from this study population (Rosenfield et al. 2016, R.N. Rosenfield, unpubl. data), I highlight that this study population had never experienced in the pre- vious 38 years spring weather as severe as that in April 2018, and so I was hesitant to predict what, demographically, to expect post-storm. Regardless, my findings are relevant to depicting how a breeding raptor population contends with severe weather, as stochastic events are projected by climate change models to be a more frequent phenomenon into the $22^{\text {nd }}$ century (USGCRP 2017).

\section{Methods}

I studied breeding Cooper's hawks during 1980-2018 in central Wisconsin, as described in Rosenfield (2018) and Rosenfield et al. (1995). My study area included the rural environments of Portage County and within the same county the abutting municipalities of Stevens Point, Whiting and Plover, with a predominately urban population of about 38,000 , and a human density of about 600/km² (US Census Bureau 2000).

Each year I find $>90 \%$ of nests before egg-laying by listening for dawn vocalizations or by searching for partially constructed nests during the pre-incubation stage, about mid-March through late April (Rosenfield 2018); all nests analyzed for 2018 were found prior to the April storm. I am thus able to examine productivity without adjusting for the biases that might have resulted from excluding breeding attempts that failed prior to discovery (Rosenfield et al. 2000).

I made at least two visits to nests to assess reproduction. One visit included climbing to nests during the mid-incubation period (about mid-May) to obtain completed clutch counts, and another climb about mid-June when nestlings were about 18 days of age, or about $70 \%$ of fledgling age, to ascertain brood size and nestling age, and band the young in the nests. This schedule avoided the criterion of $80 \%$ fledgling age suggested for other raptor species, an age at which visits could result in premature fledging of some nestlings and/or inaccurate brood counts of Cooper's hawk young (Rosenfield et al. 2007). I report average brood counts ( \pm standard error) for successful nests in 2018, which are defined as those in which at least one young reached $\geq 18$ days of age (Rosenfield et al. 2016). Hatching dates per nest were determined by backdating from estimated nestling ages of the oldest chicks based on plumage development (Rosenfield et al. 2016). I report the median hatching date for successful nests in 2018; I use the median because it is less sensitive to outliers which could skew results (Rosenfield et al. 2016). Nest success was the proportion of occupied nests that were successful (an occupied nest is one in which eggs were laid). 
Rosenfield RN: Riding the storm out: select demographics of a breeding population of Cooper's hawks (Accipiter cooperii) following a severe spring snowstorm

I identified 15 males and 1 female (she was paired with one of the 15 males) in the nesting areas before the 14-16 April storm by sighting their colored, unique alpha-numeric coded leg bands using binoculars or a spotting scope. I defined a nesting area as a nestcentered plot of $800 \mathrm{~m}$ in diameter which was occupied by a breeding adult in one or more years (this metric is the median inter-nest distance between breeding pairs in our Wisconsin study areas; Rosenfield et al. 2016). Survival of marked individuals after the storm was verified by re-sightings or re-captures in nesting areas during the nestling stage. Breeding adults are initially marked (and re-trapped in later years) when captured in mist nets with use of a live, decoy great horned owl (Bubo virginianus; see details of trapping techniques in Rosenfield (2018).

\section{Results and discussion}

I found 21 occupied nests, of which one failed at the egg stage in 2018; no adults were observed incubating eggs at any of these 21 nests prior to the April storm. The median hatch date for the remaining 20 successful Cooper's hawk nests was 10 June (range: 27 May-19 June), which was the sixth latest median hatch date in a breeding season for 39 years (1980-2018). The five later median hatch dates (of which 14 June 1982 was the latest) occurred during the first 17 years of the 39year study, and thus 2018 was the latest median hatch date in the 22 years since 1996. During this period the average median hatch date was 5 June. Accentuating the later timing of hatching in 2018, the median hatching date for the study population advanced an average of 1.3 days/decade since 1980 in accord with climate warming in Wisconsin (Rosenfield et al. 2016, RNR, unpublished data). The $\sim 3$-week period between the earliest (27 May) and latest hatching date (19 June) of young at nests in 2018 is similar to the annual average 20-day range between earliest and latest calendric timing of hatching at nests in the previous 38 years for the study population of Wisconsin Cooper's hawks (Rosenfield et al. 2016, RNR, unpublished data).

Survival was complete for a total of 16 uniquely color-marked adult Cooper's hawks (15 males and 1 female, which includes one mated pair) identified in 15 nesting areas 5-15 days prior to the 14-16 April 2018 storm. All 16 birds were present until their young had reached at least 19 days of age in the nesting area where each adult was initially observed that year.

Reproductive output of Cooper's hawks in 2018 was on average similar to Wisconsin metrics for our study species in the previous 38 years (1980-2017; Rosenfield et al. 2016, RNR, unpublished data). In 2018, average clutch size at 21 nests was $4.4 \pm 0.13$ eggs (range $3-5$ ), and average brood size at 20 successful nests was $4.0 \pm$ 0.24 nestlings (range $=3-5$ ). During 1980-2017, the overall average clutch count was 4.3 eggs/nest (range of annual averages $=3.9-4.8$ eggs; $n=648$ nests), and the average brood size per successful nest was 3.7 young (range of annual averages $=3.1-4.1$ nestlings; $n=776$ nests). Average clutch and brood sizes per successful nest have remained stable during these 38 years (Rosenfield et al. 2016, R.N. Rosenfield, unpubl. data). Furthermore, these long-term metrics are among the highest such measures for any population of Cooper's hawks in North America (Rosenfield 2018). Thus the later timing of hatching in 2018, most likely influenced by the severe spring storm, appeared to have no apparent deleterious effects on the productivity of our study population. Accentuating this conclusion, nest success during 2018 was $95 \%$, which was higher than the overall average $77 \%$ (range $=57-93 \%$ ) nest success rate in the previous 38 years (Rosenfield et al. 2000, RNR, unpublished data). Moreover, the three-week nesting period in 2018 was similar to the annual duration of three weeks for the nesting season in earlier decades (Rosenfield et al. 2016). Notably, I have been unable to show in my multi-decade studies that habitat (rural or urban, conifer plantation or non-plantation, presumptive site quality as indexed by consistency of nest area use, and high breeding density) is related to size of clutch or brood counts, nesting phenology, annual adult survival, and production of recruits, or fitness in Wisconsin Cooper's hawks (Rosenfield \& Bielefeldt 1999, Rosenfield et al. 2000, 2009, 2016). Conceivably, the apparent high quality of various Wisconsin habitats for breeding Cooper's hawks could be related to a lessening of the impacts of severe weather.

Adequate amounts of prey were probably available to support in part the survival of adults and the high reproduction in our Wisconsin nesting areas despite the severe weather early in the 2018 breeding season. It is possible that alternative, non-ground prey may have been important for the Cooper's hawks during the preincubation period (they typically use shrub- and grounddwelling prey). Indeed, I documented numerous feathers of pine siskins (Spinus pinus) at plucking posts (substrates where avian prey are delivered and plucked by adults) in 11 of the 21 nesting areas visited in April 2018. I had rarely detected feathers of pine siskins at plucking posts during the entire nesting season at Wis- 
consin-wide nest sites prior to 2018 (Rosenfield 2018). This songbird is a tree canopy species, but, unlike the American robin (a predominant prey species of Wisconsin Cooper's hawks especially during the pre-incubation period), the siskin will also use feeder stations (Dawson 1997). Thus, the siskin's use of above-ground habitat may have provided an alternative prey resource for Cooper's hawks, given the ground snow cover in April 2018. Similarly, researchers in Florida reported a heavy reliance' by breeding male Cooper's hawks on nestling songbirds taken from tree canopy nests apparently due to low levels of ground prey (Millsap et al. 2013).

Climate change models predict greater frequency of severe storms into the $22^{\text {nd }}$ century (USGCRP 2017), and so I urge raptor researchers to document in detail how birds of prey contend behaviorally and demographically with severe weather, as such responses by this group of birds are globally underreported and/or unknown (Anctil et al. 2014). My study population of Wisconsin Cooper's hawks contended favorably in one breeding season to a single severe weather event, with high nest success and average indices for clutch and brood sizes, including high adult survival. However, these results stem from one population responding to a severe weather event in a single year. If climate projections are correct, similar breeding demographics across larger temporal and spatial scales could provide more insights into the population effects of future erratic weather on raptor species.

\section{References}

Anctil A, Franke A \& Bêty J 2014: Heavy rainfall increases nestling mortality of an arctic top predator: experimental evidence and long-term trend in peregrine falcons. Oecologia 174: 1033-1043. DOI: 10.1007/S00442-013-2800-y.

Bradley NL, Leopold AC, Ross J \& Huffaker W 1999. Phenological changes reflect climate change in Wisconsin. Proceedings of the National Academy of Science, USA 96: 9701-9704.

Dawson WR 1997: Pine siskin (Spinus pinus), 1-24. In: Poole A \& Gill F (eds), The birds of North America. The Academy of Natural Sciences, Philadelphia, and The American Ornithologists' Union, Washington DC.

Dickey MH, Gauthier G \& Cadieux MC 2008: Climatic effects on the breeding phenology and reproductive success of an arctic-nesting goose species. Global Change Biology 14: 1973-1985. DOI: 10.1111/ j.1365-2486.2008.01622.x.
Franke A, Galipeau \& Nikolaiczuk L 2013: Brood reduction by infanticide in peregrine falcons. Arctic 66: 226-229.

Gaston AJ, Gilechrist HG \& Mallory ML 2005: Variation in ice conditions has strong effects on the breeding of marine birds at Prince Leopold Island, Nunavut. Ecography 28: 331-344. DOI: 10.1111/ j.0906-7590.2005.04179.x.

Hunter CM, Caswell H, Runge MC, Regehr EV, Amstrup SC \& Stirling I 2010: Climate change threatens polar bear populations: a stochastic demographic analysis. Ecology 91: 2883-2897. DOI: $10.1890 / 09-1641.1$.

Krüger O 2004: The importance of competition, food, habitat, weather and phenotype for the reproduction of buzzard Buteo buteo. Bird Study 51: 125-132.

Lõhmus A 2003: Are certain habitats better every year? A review and a case study on birds of prey. Ecography 26: 545-552. DOI. 10.1034/j.16000587.1999.03575.x.

McClure CJW, Westrip JRS, Johnson JA, Schulwitz SE, Virani MZ, Davies R, Symes A, Wheatley H, Thorstrom R, Amar A, Buij R, Jones VR, Williams NP, Buechley ER \& Butchart SHM 2018: State of the world's raptors: distributions, threats, and conservation recommendations. Biological Conservation 227: 390-402. DOI: 10.1016/j.biocon. 2018.08.012.

Millsap BA, Breen TF \& Phillips LM 2013: Ecology of the Cooper's hawk in north Florida. North American Fauna 78: 1-58. DOI: 10.3996/nafa.78.0001.

Møller AP, Fielder W \& Berthold P 2010. Effects of climate change on birds. Oxford University Press, Oxford.

National Climatic Data Center. Retrieved November 30, 2018, from http://www.ncdc.noaa.gov/oa/ dataaccesstools.html\#climate.

Newton I, McGrady MJ \& Oli MK 2016: A review of survival estimates for raptors and owls. Ibis 158: $227-$ 248. DOI: 10.1111/ibi.12355.

Rodriguez CR \& Bustamante J 2003: The effect of weather on lesser kestrel breeding success: can climate change explain historical population declines? Journal of Animal Ecology 72: 793-810. DOI: 10.1046/j.1365-2656.2003.00757.x.

Rosenfield RN 2018: The Cooper's hawk: breeding ecology and natural history of a winged huntsman. Hancock House Publishers, Blaine, USA.

Rosenfield RN \& Bielefeldt J 1999: Mass, reproductive biology, and nonrandom pairing in Cooper's hawks. 
Auk 116: 830-835.

Rosenfield RN, Grier JW \& Fyfe RW 2007: Reducing management and research disturbance, 351-364. In: Bird DM \& Bildstein KL (eds), Raptor research and management techniques. Hancock House Publishers, Blaine, USA.

Rosenfield RN, Bielefeldt J, Affeldt JL, \& Beckmann DJ 1995: Nesting density, nest area reoccupancy, and monitoring implications for Cooper's hawks in Wisconsin. Journal of Raptor Research 29: 1-4.

Rosenfield RN, Bielefeldt J, Sonsthagen SA \& Booms TL 2000. Comparable reproductive success at conifer plantation and non-plantation nest sites for Cooper's hawks in Wisconsin. Wilson Bulletin 112: 417-421.

Rosenfield RN, Bielefeldt J, Rosenfield LJ, Booms TL \& Bozek MA 2009: Survival rates and lifetime reproduction of breeding male Cooper's hawks in Wisconsin, 1980-2005. Wilson Journal of Ornithology 121: 610-617.

Rosenfield RN, Hardin MG, Bielefeldt J \& Keyel ER 2016: Are life history events of a northern breeding population of Cooper's hawks influenced by changing climate? Ecology and Evolution 7: 399408. DOI: $10.1002 /$ ece3.2619.

Serbin SP \& Kucharik CJ 2009: Spatiotemporal mapping of temperature and precipitation for the development of a multi-decadal climatic dataset for Wisconsin. Journal of Applied Meteorology and
Climatology 48: 742-757. DOI: $10.1175 / 2008$ JAMC1986.1.

Stirling I \& Derocher AE 2012: Effects of climate warming on polar bears: a review of the evidence. Global Change Biology 18: 2694-2706. DOI: 10.1111/j.1365-2486.2012.02753.x.

US Census Bureau 2000. US Census 2000: US Dept of Commerce, Washington DC. Retrieved December 30, 2018, from http://www.census.gov/main/ www/cen2000.html.

USGCRP 2017: Climate Science Special Report 2017: 4th National climate Assessment, Volume 1. Wuebbles DJ, Fahey DW, Hibbard KA, Dokken DJ, Stewart BC \& Maycock TK (eds), US Global Change Research Program, Washington DC. DOI: 10.7930/J0J964J6.

Wellicome TI, Fisher RJ, Poulin RG, Todd LD, Bayne EM, Tyler Flockhart DT, Schmutz JK, De Smet K \& James PC 2014: Apparent survival of adult burrowing owls that breed in Canada is influenced by weather during migration and on their wintering grounds. Condor 116: 446-458. DOI: 10.1650/ condor-13-161.1

Whelan S, Strickland D, Morand-Ferron J \& Norris DR 2017: Reduced reproductive performance associated with warmer ambient temperatures during incubation in a winter-breeding, food-storing passerine. Ecology and Evolution 7: 3029-3036. DOI: 10.1002/ ece3.2864. 